\title{
Nationwide Survey of Blood Culture Performance Regarding Skin Disinfection, Blood Collection and Laboratory Procedures
}

\author{
Jeong Hwan Shin', Sae Am Song', Mi-na Kim², Sunjoo Kim ${ }^{3}$ \\ ${ }^{1}$ Department of Laboratory Medicine and Paik Institute of Clinical Research, Busan Paik Hospital, Inje University \\ College of Medicine, Busan, ${ }^{2}$ Department of Laboratory Medicine, University of Ulsan College of Medicine and Asan \\ Medical Center, Seoul, ${ }^{3}$ Department of Laboratory Medicine and Institute of Health Sciences, \\ Gyeongsang National University School of Medicine, Jinju, Korea
}

Background: Although many laboratories use automated blood culture systems, adequate skin disinfection and optimal blood volume are still critical for successful culture. The authors undertook a nationwide survey to understand the current situation and problems of blood culture in Korea.

Methods: A survey of blood culture was performed in March and April 2010, including disinfectants, blood collection intervals, and recommended blood volumes. The laboratory physicians described the storage condition of culture bottles before delivery to the equipment. For quality control, the positive rate and skin contamination rate were studied.

Results: Replies to the survey were collected from 74 Korean hospitals. Povidone iodine after either isopropyl alcohol or ethanol application was the most common means of skin disinfection. Sampling of a second set of cultures was performed simultaneously in $38 \%$ of hospitals and after a 30 -min interval in
$50 \%$. The recommended blood volume was $10 \mathrm{~mL}$ in most cases $(69 \%)$, but was $20 \mathrm{~mL}$ in $24 \%$ of cases. The bottles were stored at $37^{\circ} \mathrm{C}$ before installation in $23 \%$ of cases and at room temperature in $16 \%$, whereas $57 \%$ were placed directly in the equipment during the night shift. Positive rates ranged $8-10 \%$ in $32 \%$ of hospitals, $5-8 \%$ in $23 \%$, and $<5 \%$ in $12 \%$. Skin contamination rates were $2-3 \%$ in $32 \%$ of hospitals, $1-2 \%$ in $27 \%$, and $>3 \%$ in $13 \%$.

Conclusion: Skin disinfection methods were rather variable. Sampling interval, blood volume, and storage of bottles should be standardized. More than $10 \%$ of the hospitals require quality improvement in terms of positive rate and skin contamination rates. (Korean J Clin Microbiol 2011;14:91-96)

Key Words: Sepsis, Bacteremia, Blood culture, Contamination, Disinfection

\section{INTRODUCTION}

As automated blood culture systems have been established in many hospitals, it is possible to diagnose bacteremia quickly and sensitively. In spite of the advances in equipment, however, skin disinfection, number of cultures, and blood volume are still critical factors for successful culture [1,2].

The criteria for skin normal flora should be established, and clinicians should interpret carefully about whether a microorganism recovered in blood culture is a true pathogen or a contaminant. To reduce the isolation of normal skin flora, skin disinfectants should be adequately used. Various researches have been performed about the effectiveness of these disin-

Received 14 December, 2010, Revised 7 February, 2011

Accepted 8 March, 2011

Correspondence: Sunjoo Kim, Department of Laboratory Medicine, Gyeongsang National University Hospital, 90 Chilam-dong, Jinju 660-702, Korea. (Tel) 82-55-750-8239, (Fax) 82-55-762-2696, (E-mail) sjkim8239@hanmail.net fectants. Although it was recommended in the past that a second blood collection be conducted 30 minutes to 1 hour after the first sampling, the recent guidelines of the Clinical and Laboratory Standards Institution (CLSI) recommended that the two blood collections be taken at the same time on another site $[1,3]$. There have been several reports testifying that there is no significant difference in culture results according to the sampling interval $[4,5]$. Because sepsis is a serious illness, it would be better to begin antibiotic therapy promptly after finishing blood collection, arguing against a gap between the harvesting of the first and second samples. Moreover, the number of blood cultures as well as their volume is more important than timing in enhancing the yield. One set of blood cultures is inadequate; two or three sets are required in the adulthood $[3,6,7]$. It is recommended to take at least $20 \mathrm{~mL}$ of blood from one venipuncture $[3,6,8]$. A blood culture bottle arriving in the clinical microbiology laboratory should not be stored in a refrigerator 
but rather be put into the equipment immediately. When the equipment is not available, the bottle should be stored at room temperature. If it is stored at $37^{\circ} \mathrm{C}$, a false result can be observed due to the growth of bacteria [9]. The rate of positive cultures and the rate of contamination with skin normal flora are good indicators of blood culture performance [3,10]. Each laboratory should provide these data every year, and frequent communication with physicians is necessary.

To decrease contamination by skin normal flora and to increase the yield of actual pathogens, continuous quality improvement efforts should be made. Against this background, this study captured the status and problems of blood cultures in Korea.

\section{MATERIALS AND METHODS}

\section{Institutions}

In February 2010, a questionnaire was distributed through e-mail to all members of the Korean Society for Laboratory Medicine. It inquired about the type of medical institution, the size of the hospital, and the number of blood cultures performed for 1 year. The answers were collected throughout March and April.

\section{Skin disinfection}

The type of skin disinfectants used and the waiting time after its application were investigated according to patient age group. The type of disinfectants for the rubber cap of the injection port of blood culture bottle also was requested.

\section{Blood collection}

Who collects blood for culture was examined in general wards, intensive care units, and emergency departments. The number of blood cultures, the recommended volume of blood, type of culture bottle used for adults or children, as well as the sampling interval were surveyed.

\section{Detection procedure in clinical microbiology laboratory}

Manufacturers of automated blood culture systems used in the laboratory were described. The storage temperature before installation into the culture equipment, the method of interim reporting when bacteria grow, and the total incubation period was investigated. The positive rate as well as the contamination rate of skin normal flora was reported. We did not specify the definition of positive rate and contamination rate, but rather used those data of each hospital directly. The performance of susceptibility testing of skin contaminants was inquired.

\section{RESULTS}

\section{Participating medical institutions}

Eighty-two medical institutions including 47 university hospitals, 30 general hospitals, and 5 commercial laboratory centers returned the questionnaire. Three institutions not performing blood culture and 5 commercial laboratory centers conducting blood cultures mainly as reference laboratories were excluded for the analysis. Among the remaining 74 hospitals, those with $500-1,000$ beds are accounted for $62.2 \%$, followed by $200-500$ beds $(21.6 \%)$, more than 1,000 beds $(12.2 \%)$, and less than 200 beds $(4.1 \%)$. They were scattered all over the country.

\section{Number of blood cultures}

The number of blood cultures performed in 2009 was categorized as $<5,000$, 5,000-10,000 10,000-20,000, 20,000-30,000, $30,000-40,000$, and $>40,000$ in $20.3 \%, 14.9 \%, 27.0 \%, 16.2 \%$, $12.2 \%$, and $9.5 \%$ of institutions, respectively. On average, 2,364 blood cultures (SD 1,316) per 100 beds were conducted for a year, ranging from 154 to 5,320 .

\section{Skin disinfection}

There was no significant difference in skin disinfectants used in adults, children, and neonatal infants. Povidone iodine (PI) after isopropyl alcohol (IPA) accounted for $44.6 \%$, followed by PI after applying ethanol in $20.3 \%$ for adults (Fig. 1). The other age groups showed a similar pattern of skin disinfectant use. Using PI alone was reported for $12.2 \%$ of adults and $16.2 \%$ of neonatal infants. Using alcohol such as IPA or ethanol alone was seen in $8.1 \%$ of adults and children and $9.5 \%$ of neonatal infants. Chlorhexidine was used only in one institution. The waiting time was slightly different according to the type of disinfectant. Blood was collected immediately from 18.9\%, $8.1 \%$, and $5.4 \%$ in whom IPA, ethanol, and PI was used respectively. For PI, 16.2\% waited for less than $30 \mathrm{sec}$, and $21.6 \%$ waited for longer than $2 \mathrm{~min}$ or until dried (data not shown). The injection port of the culture bottle was disinfected in $75.6 \%$ of cases, not in $10.8 \%$. Data were not provided from the remaining hospitals. For disinfection of the injection port, PI (27.0\%) was used most frequently, followed by IPA (18.9\%) and ethanol (13.5\%). 


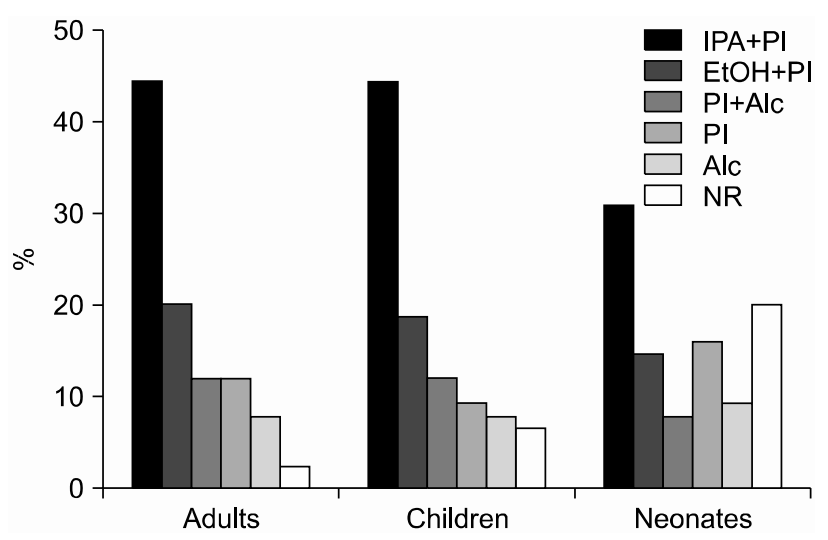

Fig. 1. Disinfectants for the skin preparation of blood culture. IPA, isopropyl alcohol; PI, povidone iodine; EtOH, ethanol; Alc, isopropyl alcohol or ethanol; NR, no response.

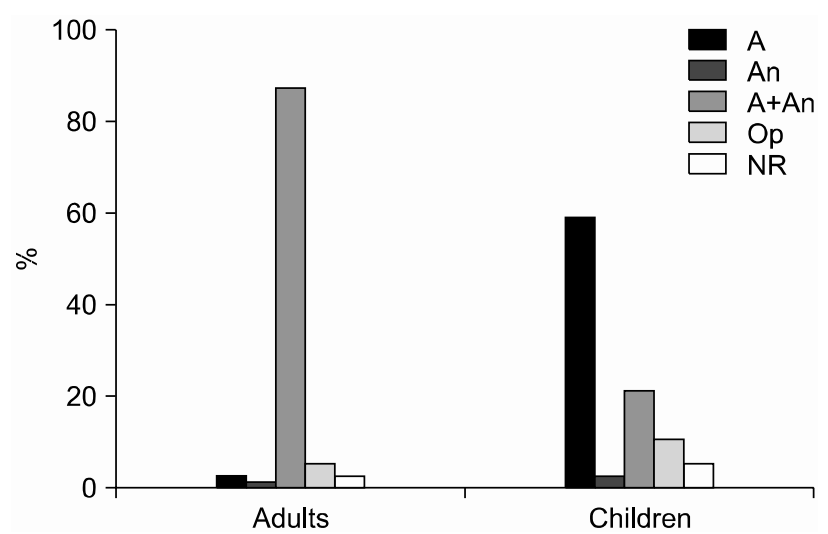

Fig. 2. Use of blood culture bottles. A, aerobic; An, anaerobic; Op, optional anaerobic; NR, no response.

\section{Blood collection}

Blood was largely collected by the same medical personnel at general wards, intensive care units (ICU), and emergency departments (ED). Interns, nurses, and dedicated phlebotomists collected blood in $51.4 \%, 17.6 \%$, and $6.8 \%$, respectively, in the general wards. Two and three types of vocation worked together for sampling in $20.3 \%$ and $4.1 \%$, respectively, which is similar to the ICU or ED (data not shown). The recommended number of blood collections was two, three, and two or three in $4.1 \%$, $27.0 \%$, and $67.6 \%$, respectively. The recommended blood volume was $10 \mathrm{~mL}$ in $68.9 \%$ and $20 \mathrm{~mL}$ in $24.3 \%$. A set of aerobic and anaerobic bottles was used for adults in $87.8 \%$, whereas $5.4 \%$ of hospitals added an anaerobic bottle only in cases of suspected anaerobic bacterial infection (Fig. 2). For children, a set of aerobic and anaerobic bottles was utilized in $21.6 \%$ and an aerobic bottle alone in $59.5 \%$, with an anaerobic bottle added
Table 1. Positive rate and contamination rate of blood cultures in 74 hospitals

\begin{tabular}{lrlllll}
\hline \multicolumn{3}{c}{ Positive rate } & & \multicolumn{3}{c}{ Contamination rate } \\
\cline { 1 - 2 } \cline { 5 - 6 } \cline { 5 - 6 } Range & $\mathrm{N}$ & $(\%)$ & & Range & $\mathrm{N}$ & $(\%)$ \\
\hline $1-5 \%$ & 9 & $(12.2)$ & & $0-1 \%$ & 17 & $(23.0)$ \\
$5-8 \%$ & 17 & $(23.0)$ & & $1-2 \%$ & 20 & $(27.0)$ \\
$8-10 \%$ & 24 & $(32.4)$ & & $2-3 \%$ & 24 & $(32.4)$ \\
$10-15 \%$ & 12 & $(16.2)$ & & $>3 \%$ & 10 & $(13.5)$ \\
$>15 \%$ & 3 & $(4.1)$ & No response & 3 & $(4.1)$ \\
No response & 9 & $(12.2)$ & & & \\
\hline
\end{tabular}

optionally according to the clinical situation in 10.8\%. Blood was collected from both arms at the same time, with a 30-min or a 1 -h interval in $37.8 \%, 50.0 \%$, and $5.4 \%$, respectively.

\section{Blood culture equipment, storage of blood collected bottle and reporting system}

An automated blood culture system was utilized in $87.8 \%$ of the institutions. The manufacturing companies were bioMerieux Inc., Becton Dickinson (BD), and both in 54.1\%, 23.0\%, and $10.8 \%$, respectively. The most common models were the BacT/Alert 3D (bioMerieux Inc, Durham, NC) or Bactec 9240 (BD Diagnostics, Sparks, MD). When blood culture bottles arrived at night, they were put into the system directly in $56.8 \%$ of hospitals. In the other cases, storage at room temperature and at $37^{\circ} \mathrm{C}$ was found to be almost identical, at $16.2 \%$ and $23.0 \%$, respectively. When blood culture revealed a positive result, it was reported to the medical staff by phone $(23.0 \%)$, short message service (SMS) or PDA (12.2\%), laboratory information system $(23.0 \%)$, or a combination $(24.3 \%)$. The culture period was generally 5 days for the automated system and 7 days for the manual method. However, five institutions incubated for 7 days despite their use of automated systems.

\section{Positive rate and contamination rate}

The rate of positive blood cultures was examined every year in $88 \%$ of the institutions. The positive rate was classified as $<5 \%, 5-8 \%, 8-10 \%, 10-15 \%$, and $>15 \%$ in $12.2 \%, 23.0 \%$, $32.4 \%, 16.2 \%$, and $4.1 \%$, respectively (Table 1 ). The rate of contamination with skin normal flora was reported in most hospitals $(94.6 \%)$. The contamination rate was $<1 \%, 1-2 \%, 2-3 \%$, and $>3 \%$ in $23.0 \%, 27.0 \%, 32.4 \%$ and $13.5 \%$, respectively. Susceptibility testing of contaminants was conducted routinely in $63.3 \%$ of institutions and only when requested in $16.2 \%$. Susceptibility testing was not performed in $10.8 \%$. 


\section{DISCUSSION}

This study was designed to capture the current situation and problems of blood culture in Korea. Whether blood culture is conducted appropriately has rarely been evaluated. The data of 74 institutions located throughout the country were analyzed. The total number of blood cultures performed in the laboratory might differ according to the severity and distribution of patients at each hospital. If skin disinfection is inadequate, normal skin flora grow during blood culture which is hard to discriminate from true pathogens. The methods of disinfection were diverse. Although using PI after applying IPA or ethanol was the most common, using either PI or alcohol alone was also reported. In this study, the frequency of relying on PI alone was the highest for neonatal infants. This practice is of concern, as iodine is inappropriate for this population with the potential to affect thyroid function through skin absorption [11]. Thus, if PI is used, removing it with alcohol or normal saline is needed $[8,12]$. Chlorhexidine is rarely used, although some authors endorsed the superiority of chlorhexidine to PI [12-14]. For PI, the most frequently used skin disinfectant, the waiting time was less than $30 \mathrm{sec}$ in $21.6 \%$, meaning that the time allowed for disinfection is insufficient. The CLSI guidelines stated that the disinfection power of tincture of iodine, chloride peroxide, and chlorhexidine gluconate is superior to that of PI [3]. Whereas PI requires 1.5 to $2 \mathrm{~min}$ to produce disinfection, tincture of iodine or chlorhexidine gluconate shows a disinfection effect within 30 sec $[12,14,15]$. Therefore, the optimal usage of various products for disinfection should be reviewed. Standardization of skin disinfection is highly desirable in view of the results of diverse skin preparation.

The cap of the blood culture bottle is made of rubber, and PI can cause cracks [6]. Pseudobacteremia can occur secondary to growth of Pseudomonas spp. or Burkholderia spp. in povidone solution [16], so alcohol is recommended to disinfect the cap of the bottle [8]. Nevertheless, this questionnaire survey found that PI was utilized most frequently for disinfection of the injection port. In some countries, dedicated phlebotomist teams take all samples for blood culture. However, interns collected blood in around $50 \%$ suggesting that dedicated phlebotomist teams are not activated yet in Korea. The number of blood cultures was two or three in $67.5 \%$ of the institutions. Many previous studies reported that three blood collections enhance the positive rate significantly $[7,8]$. More concrete data might be needed for the number of blood culture requested.
One of the most critical factors in successful blood culture is the amount of blood [3,10]. For adults, 20 to $30 \mathrm{~mL}$ per one venipuncture is recommended and is divided evenly into the aerobic and anaerobic bottles [5,8,10]. Because the culture bottle has negative pressure, care is necessary to avoid putting too much blood into one bottle. As most pathogens causing sepsis are aerobic, if the sample is not of the desirable amount, it should be put into the aerobic bottle first [3]. Although an anaerobic bottle can be added whenever one suspects anaerobic bacteremia, it is not easy to use this protocol in routine work. Collecting $20 \mathrm{~mL}$ of blood from sepsis patients is tricky and difficult. Therefore, many institutions seemed to recommend drawing $10 \mathrm{~mL}$ of blood instead. As children are known to have high bacterial counts in the blood in cases of bacteremia, a small amount of blood is sufficient [2,8], and use of a pediatric culture bottle is recommended. These bottles are designed for a small amount of blood and include resin or charcoal to neutralize bacterial growth inhibitors. However, we found that a considerable number of hospitals used the same bottle employed for adults; only $47.2 \%$ utilized pediatric bottles (data not shown). Use of a pediatric bottle should be encouraged for children.

The current CLSI guidelines recommended collecting the second blood sample from another site at the same time [3]. However, only $37.8 \%$ of institutions adopted the new guidelines, and more than half of the hospitals still used the interval of $30 \mathrm{~min}$ to $1 \mathrm{~h}$. Although the previous guidelines said that most bacteremia is intermittent and the time interval of $30 \mathrm{~min}$ to $1 \mathrm{~h}$ provides a greater opportunity to detect bacteria, several reports showed that there is no difference in the detection rate according to the interval of blood collection $[4,5]$.

Around half of institutions could not put the sample bottles into the automated culture system directly at night. More hospitals stored them at $37^{\circ} \mathrm{C}$ rather than at room temperature. Because the automated blood culture system examines bacterial growth with a change of $\mathrm{pH}$ caused by $\mathrm{CO}_{2}$ in a bottle after a certain period of time, if bacteria grow at $37^{\circ} \mathrm{C}$, the growth can lead to false results [9]. Therefore, when direct installation of bottle is not available, the culture bottle arriving at night should be stored at room temperature and then transferred to the clinical microbiology laboratory the next morning. When bacteria grow, reporting the result of a Gram stain is very helpful [10], especially when it comes to gram-negative rods, because these organisms have a minimal possibility of skin contamination $[6,15]$. As gram-positive cocci are more likely to be skin con- 
taminants, their results should be interpreted carefully. This study found that positive blood cultures were reported in diverse ways, including phone, PDA, and cell phone. An interim report of negative results was made within 2-3 days. So, the reporting system is considered to be acceptable.

The positive rate of blood culture ranged from $8-10 \%$ in most institutions. For the institutions recording a $<5 \%$ of positive rate, the amount of blood should be checked $[17,18]$. When the skin contamination rate is $>3 \%$, skin disinfection procedure should be reviewed. More than $10 \%$ of the hospitals showed either $<5 \%$ of positive rate or $>3 \%$ of contamination rate, requiring quality improvement. Continuous education of medical personnel for a sufficient amount of blood or on proper skin preparation is needed [17-19]. Providing medical staff with a well-described guideline on blood culture will be helpful. Susceptibility testing was performed for most skin flora, which may induce unnecessary use of antimicrobial agents. According to previous reports, susceptibility testing of skin flora raised medical costs and extended the length of hospital stay [3,5]. A general consensus about the susceptibility test should be formed for the normal flora.

A limitation of this study is that the survey relied on written answers rather than being conducted on the spot. There might be some chances of wrong answers if the respondents did not know the procedure completely. When a respondent did not answer some questions, the total percentage is $<100 \%$ in the results. Precise definition of positive rate and skin contamination rate lacked. Hospitals and institutions were used as the same meaning in this article.

In conclusion, skin disinfection method was rather variable. Sampling interval, blood volume, and storage of bottles should be standardized. More than $10 \%$ of the hospitals are required for quality improvement in terms of positive rate and skin contamination rates.

\section{ACKNOWLEDGMENTS}

The authors appreciate greatly for the all colleagues who responded to the questionnaire. This study was supported by the Quality Improvement Committee of Korean Society for Laboratory Medicine.

\section{REFERENCES}

1. Lamy B, Roy P, Carret G, Flandrois JP, Delignette-Muller ML. What is the relevance of obtaining multiple blood samples for culture? A comprehensive model to optimize the strategy for diagnosing bacteremia. Clin Infect Dis 2002;35:842-50.

2. Mylotte JM and Tayara A. Blood cultures: clinical aspects and controversies. Eur J Clin Microbiol Infect Dis 2000;19:157-63.

3. Clinical and Laboratory Standards Institute. Principles and procedures for blood cultures. Approved guideline. Document M47-A. Wayne, PA; Clinical and Laboratory Standards Institute, 2007.

4. Li J, Plorde JJ, Carlson LG. Effects of volume and periodicity on blood cultures. J Clin Microbiol 1994;32:2829-31.

5. Shafazand $\mathrm{S}$ and Weinacker $\mathrm{AB}$. Blood cultures in the critical care unit: improving utilization and yield. Chest 2002;122:1727-36.

6. Reimer LG, Wilson ML, Weinstein MP. Update on detection of bacteremia and fungemia. Clin Microbiol Rev 1997;10:444-65.

7. Cockerill FR 3rd, Wilson JW, Vetter EA, Goodman KM, Torgerson CA, Harmsen WS, et al. Optimal testing parameters for blood cultures. Clin Infect Dis 2004;38:1724-30.

8. Chandrasekar PH and Brown WJ. Clinical issues of blood cultures. Arch Intern Med 1994;154:841-9.

9. Lemming L, Holt HM, Petersen IS, Østergaard C, Bruun B. Bactec 9240 blood culture system: to preincubate at 35 degrees $\mathrm{C}$ or not? Clin Microbiol Infect 2004;10:1089-91.

10. Riedel S and Carroll KC. Blood cultures: key elements for best practices and future directions. J Infect Chemother 2010;16:301-16.

11. Linder N, Davidovitch N, Reichman B, Kuint J, Lubin D, Meyerovitch J, et al. Topical iodine-containing antiseptics and subclinical hypothyroidism in preterm infants. J Pediatr 1997;131: 434-9.

12. Calfee DP and Farr BM. Comparison of four antiseptic preparations for skin in the prevention of contamination of percutaneously drawn blood cultures: a randomized trial. J Clin Microbiol 2002;40:1660-5.

13. Barenfanger J, Drake C, Lawhorn J, Verhulst SJ. Comparison of chlorhexidine and tincture of iodine for skin antisepsis in preparation for blood sample collection. J Clin Microbiol 2004;42: 2216-7.

14. Malani A, Trimble K, Parekh V, Chenoweth C, Kaufman S, Saint S. Review of clinical trials of skin antiseptic agents used to reduce blood culture contamination. Infect Control Hosp Epidemiol 2007; 28:892-5.

15. Hall KK and Lyman JA. Updated review of blood culture contamination. Clin Microbiol Rev 2006;19:788-802.

16. Panlilio AL, Beck-Sague CM, Siegel JD, Anderson RL, Yetts SY, Clark NC, et al. Infections and pseudoinfections due to povidoneiodine solution contaminated with Pseudomonas cepacia. Clin Infect Dis 1992;14:1078-83.

17. Towns ML, Jarvis WR, Hsueh PR. Guidelines on blood cultures. J Microbiol Immunol Infect 2010;43:347-9.

18. Connell TG, Rele M, Cowley D, Buttery JP, Curtis N. How reliable is a negative blood culture result? Volume of blood submitted for culture in routine practice in a children's hospital. Pediatrics 2007;119:891-6.

19. Eskira S, Gilad J, Schlaeffer P, Hyam E, Peled N, Karakis I, et al. Reduction of blood culture contamination rate by an educational intervention. Clin Microbiol Infect 2006;12:818-21. 
=국문초록=

\section{피부 소독제, 채혈 및 검사 방법에 관한 전국적 혈액배양 조사}

${ }^{1}$ 인제대학교 의과대학 부산백병원 진단검사의학교실, 백인제기념임상의학연구소, ${ }^{2}$ 울산대학교 의과대학 서울아산병원 진단검사의학교실, ${ }^{3}$ 경상대학교 의과대학 진단검사의학교실, 건강과학원

\section{신정환 ${ }^{1}$, 송새암 ${ }^{1}$, 김미나 $^{2}$, 김선주 $^{3}$}

배경: 많은 검사실에서 자동화된 혈액배양기를 사용하고 있지만, 성공적인 배양을 위해서는 올바른 피부 소독과 충분한 채혈량이 필요하다. 저자들은 혈액배양의 현황과 문제점을 파악하고자 전국적 설문조사를 시행하였다.

방법: 2010년 3-4월 피부 소독제, 채혈 간격, 권장 채혈량 등에 관한 설문을 시행하였다. 또한 배양기에 넣기 전 보관상태, 양성률 및 피부 오염률에 대해서도 조사하였다.

결과: 수집된 자료 중 74 개 병원의 결과를 분석하였다. 피부 소독은 이소프로필 알코올이나 에탄올을 사용한 후, 포비돈 이오딘을 이용하는 방법이 가장 흔하였다. 동시 채혈은 $38 \%$ 에서 이루어졌고, 30 분 간격 채혈은 약 $50 \%$ 였다. 권장 채혈량 은 $10 \mathrm{~mL}$ 가 $69 \%, 20 \mathrm{~mL}$ 가 $24 \%$ 를 차지하였다. 야간에 혈액배양 병을 장비에 직접 넣는 것은 $57 \%, 37^{\circ} \mathrm{C}$ 보관이 $23 \%$, 실온 보관이 $16 \%$ 였다. 양성률은 $8-10 \%$ 가 $32 \%$ 로 가장 많았고, $5-8 \%$ 가 $23 \%, 5 \%$ 이내가 $12 \%$ 였다. 피부 오염률은 $2-3 \%$ 가 $32 \%, 1-2 \%$ 가 $27 \%, 3 \%$ 이상이 $13 \%$ 로 나타났다.

결론: 피부 소독 방법, 채혈 간격, 권장 채혈량, 혈액배양 병 보관은 검사실마다 다양하게 나타나 표준화가 필요하였다. 약 $10 \%$ 이상의 기관에서는 양성률이나 피부 오염률이 부적합하여, 질 향상이 요구되었다. [대한임상미생물학회지 2011;14:91-96]

교신저자 : 김선주, $660-702$, 경남 진주시 칠암동 90 경상대학교병원 진단검사의학과

Tel: 055-750-8239, Fax: 055-762-2696

E-mail: sjkim8239@hanmail.net 